\title{
カワイ島 (ハワイ諸島)の渓流における藻類相
}

\author{
(挿図 1-5)
}

渡辺仁治

Algal flora of some streams of Kauai (Hawaiian Islands)

By Toshiharu Watanabe

Kauai 島は, Oahu 島の北西約 95 マイルにあり, 面積法約 555 平方マイル, 径約 32 マ イルで，八ワイ諸島中で第 4 潘目に大きい島である. 中心に Waialeale 山を擁し，そ の山肌をけづつて, いくつかの河川が海に注ぎ, 中でも, Waimea川の浸蝕によつて生じ

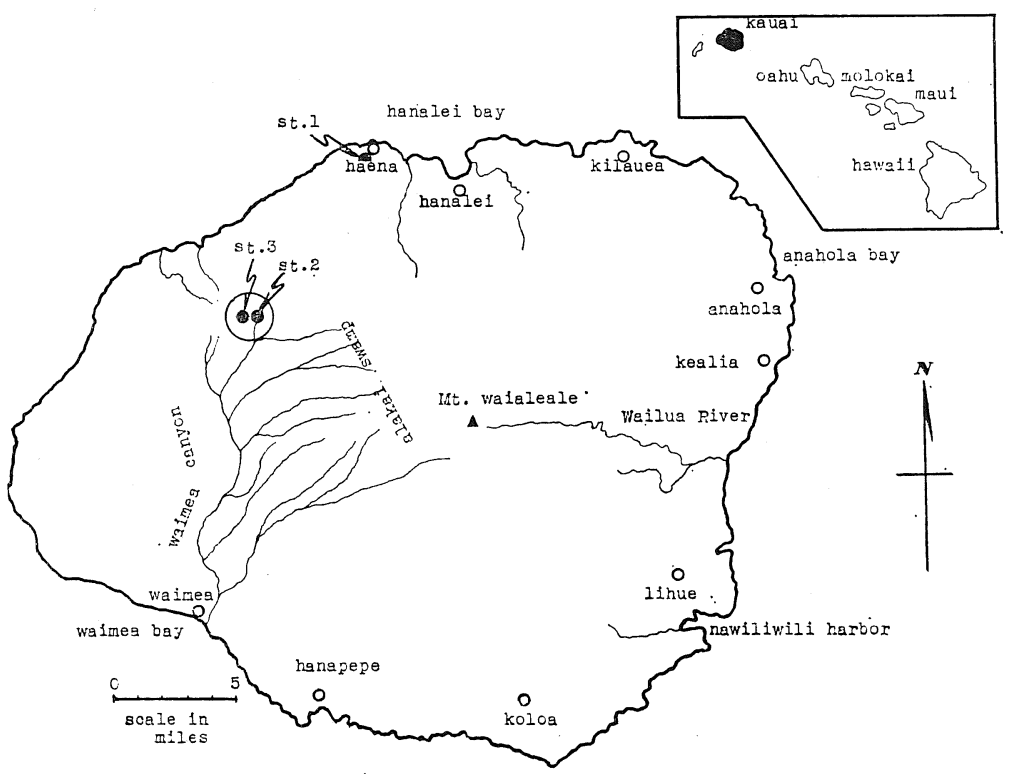

Fig. 1. Island of Kauai 
た Waimea Canyon 核钼光地として有名である。奈良女子大学の津田松苗教授は，1961 年 8 月にこの島を探訪され，その折に採集された貴重な試料を提供された，八ワイ諸島の 河川の付着藻類に関しての報文は，私の知る範囲内では皆無であり，この報文が，今後何 等かの役に立つならば幸である，改めて，津田松苗教授に深甚の謝意を表するものである.

\section{採 集 地 点}

Station 1 は，島の北岸 Hanalei の西方の Dry Cave と Wet Cave の中間にある小さい 渓流で，周国は森林に国まれ，落烡の堆積が多い，Station 2 は，南西岸に注ぐ Waimea 川の支流で，石碟の付着物は茶褐色呈し，水は酸性である (Kokee camps の付近).

Station 3 は, Kauaikoi 川 (Waimea 川の支流)の支流で, 幅約 $3 \mathrm{~m}$ の清洌な水の小渓流 である、USINGERが，当時この渓流でカゲロウの卵の孵化実験を行なつていた。また，こ の小川には涌水が流入しているようである (Fig. 2).

な扮試料は，総て石碟に付着する藻類を，ブラシで削り落したものである。

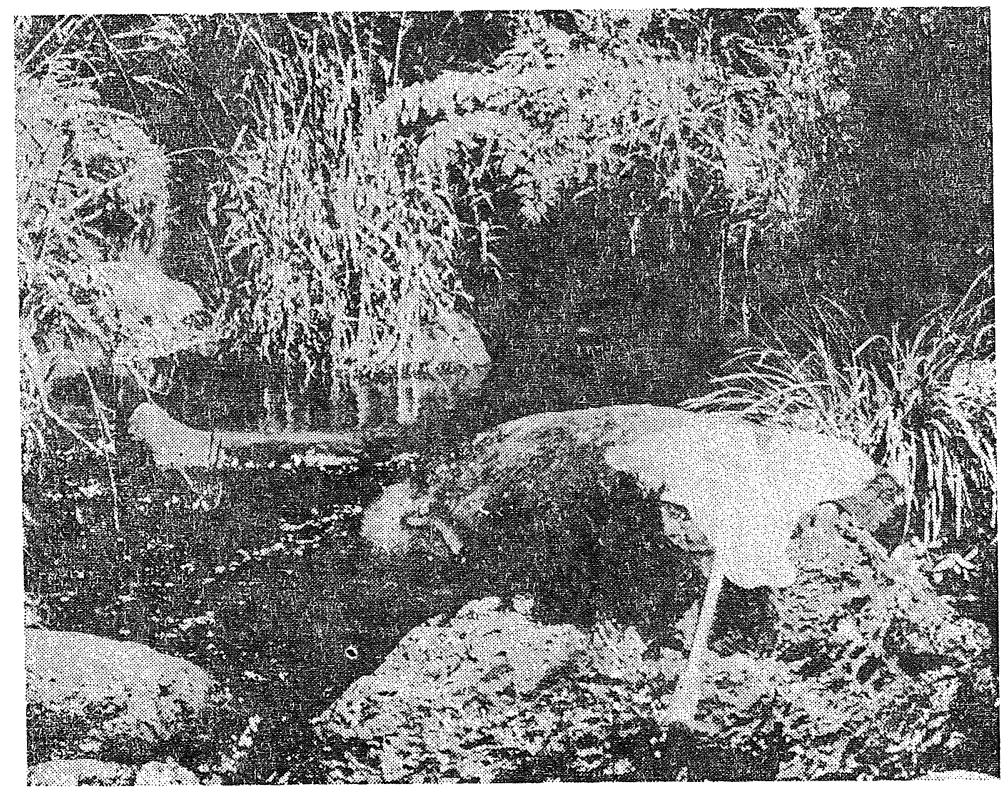

Fig. 2. Tributary of the Kauaikoi River, St. 3

珪藻以外の藻類

Station 1 に出現する藻類を列挙すると 
Stigeoclonium lubricum (DıLlw.) Küтz. $\quad+++$

Spirogyra sp. $\quad+++$

Oscillatoria pseudogeminata $\mathrm{G}$. Schмidт $\quad++$

Lyr.gbya aerugineo-coerulea (Küтz.) GoмоNт + +

L. polysiphoniae FRÉMY $\quad+$

の 5 種で，S. lubricum は本邦の多くの渓流に普通にみられる世界普遍種である. $O$. pseudogeminata は, ビルマ,インドの河川に, 他の藻類と混つて, しばしば出現する種で ある (1959). またLyngbya の 2 種はともに本州の諸温泉から報告されている(1957).

Station 2 では, 接合藻類が比較的多く,

Sphaerozosma excavatum RaLFs +++

Hyalotheca dissiliensis var. tatrica RACIB. ++

Closterium intermedium RALFs +

Penium sp. $\quad++$

Oedogonium sp. $\quad+$

Staurastrum sp. $\quad+$

の 6 種が出現して, 酸性河川としての藻類相の特色を示している.これらのうち, 前 3 者 はともに，世界各地に広く分布する普遍種である。また藍藻類では，世界普遍種である Oscillatoria tenuis AG. et Gomont が多産して優占種となつている. Oscillatoria ornata var. crassa RAO, C.B., O. chalybea var. insularis GARDNER は，ともにそれらの基本 種が，日本の温泉等から少数例で注あるが報告されている(1957). Phormidium purpurascens (KüTz. ) GoMoNT は世界普遍種であるが，少数個体が出現したにすぎず，緑藻類 の普遍種である Bulbochaete Brebissonii Kürz. は，比較的多数個体産出した．尚試料が 茶褐色呈するのは, 接合藻類の Closterium intermedium, Perium sp., Oedogonium sp. の呈色によるものである.

Station 3 では付着性藍藻類の Leptochaete crustacea BoRGEI が完全な優占種で, 接 合藻類の Zygnema pectinatum (VAUCH.) C.A.AGARDH が次いで多産しているが，これ らの種は, 少数個体を産出する接合澡類の Penium curtum BRÉB. とともに世界普遍種 である。また，藍藻類のScytonema milei BoRNET et BoRn et FLAH，接合藻類の Netrium sp. はともに珍奇な種と考えられ，Micrasterias trurcata (CORDA) BRÉB. は特異な変異 型を呈している.

上記のように, Station 2 に接合藻類が比較的多産する以外は, どの地点も, 珪藻以外 の藻類の出現種数は少なく, また, 各地点での共通種は 1 種も認められない.

珪

藻

各地点に出現した珪藻の総てを, Table 1 に表示し, 種名の判明したものの総てをPlate 
1〜3に図示した．これらの珪藻は，19属 61 種 24 変種 3 品種を数えることができ，これら のうち, 約半数の種は世界普遍種である. 正, 比較的種類に富む属として次の 4 属を挙 げることができる。すなわち，Eunotia，Navicula, Gomphonema, Nitzschiaであるが， これらの属に包含される種数が多い事実は, 日本での一般河川の場合にも度々見うけられ る.

Table 1. Bacillariophyceae-flora in the streams in the Island of Kauai

Species

Melosira varians C. A. AG.

Triceratium Javanicum Cleve

Tabellaria focculosa (Rотн) Küтz.

Fragilaria capucina var. lanceolata GRUN.

$F$. construens var. subsalina Hust.

$F$. virescens RaLfs

$F$. virescens var. oblongella GuUn.

Synedra ulna (Nitzsch) EHR.

S. amphicephala Küтz.

S. minuscula GRUN.

S. famelica KÜrz.

S. rumpens Küтz.

Eunotia praerupta EHR.

E. indica Grun.

E. arcus var. bidens Grun.

E. polydentula BRuN.

E. pectinalis var. minor (KüTz.) RABH.

E. pectinalis var. minor f. impressa (EHR.) Hust.

E. pectinalis var. minor f. intermedia KRAssKe

E. pectinalis var. undulata (RALFs) RBH.

E. lunaris var. subarcuatus (NAEG.) GRUN.

Cocconeis placentula var. euglypta (EHR.) CLEVE

C. placentula var. lineata (EHR.) CLEVE

Achnanthes Biasolettiana KÜтz.

A. affinis Grun.

A. exigua Grun.

Rhoicosphenia curvata (KÜTz.) GRUN.

Frustulia rhomboides var. saxonica (RABH.) DE ToNI

$F$. vulgaris var. asiatica $\mathbf{S} \mathrm{kV}$.

Gyrosigma Kützingii (GRUN.) CleVE

Caloneis sp.?

Navicula minima var. atomoides (GRUN.) CLEvE

N. mutica Küтz.?
St. 1 St. 2 St. 3

$++$

$+$

$++t+$

$+$

$++\quad+$

$+$

$++$

$++$

$+t$

$+\quad+$

$++$

$+$

$+$

$+++$

$++$

$+$

$++$

$++$

$+$

$+$

$++$

$++$

$++++$

$++++$

$+$

$+$

$+\quad++$

$+$

$+$

$+$

$+$

$+$ 
N. ventralis var. Okamurae Skv.

$N$. cryptocephala Küтz.

$N$. cryptocephala var. veneta (KÜTz.) GRUN.

$N$. vercunda Hust.

N. falaisiensis var. lanceola GRUN

N. exigua (Gregory) O. MÜLLeR

N. Kuripanensis Host.

Pinnularia divergens var. sublinearis CLEVE

$P$. gibba f. subundulata MAYER

$P$. maior var. transversa A.S.

$P$. viridis var. sudetica (HuLse) Hust.

Cymbella turgida (GRegory) $\mathrm{CLEVE}_{\mathrm{LE}}$

C. ventricosa KÜтz.

C. gracilis ( $\mathrm{RABH}) \mathrm{CLEVE}_{\mathrm{LE}}$

C. tumida (BRÈBISSON) VAN HEURCK

C. sp.

Gomphonema parvulum KÜtz.) GRUNOw

G. angustatum (KÜтz.) RABH.

$G$. helveticum BRUN.

$G$. longiceps var. subclavata Grun.

G. subclavatum GRUN.

G. constrictum EHR.

G. olivaceum var. minutissima Hust.

G. abbreviatum AGARDH? KÜTZ.

Nitzschia tryblionella var. levidensis (W. SMItH) Grun.

$N$. tryblionella var. devilis (ARNOTT) A. MAYER

$N$. pseudoamphioxys Hust.

N. fonticola Grun.

N. paleacea Grun.

$N$. obtusa var. scalpelliformis GRUN.

$N$. filiformis (W. Sмiтн) Hust.

$N$. reversa Wm. Sm.

Surirella linearis W. SмIтн

S. angustata KüTz.

S. robusta var. armata Hust.

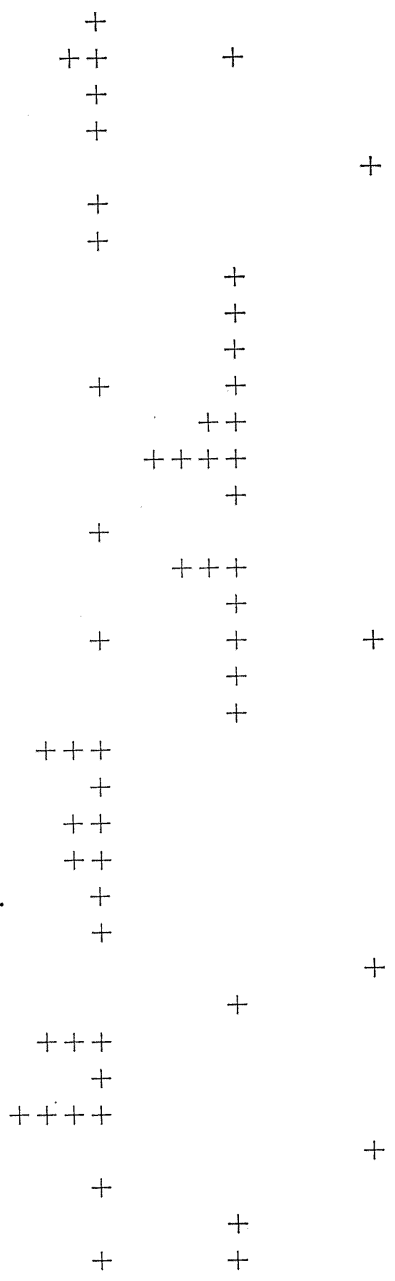

Station 1 この地点では出現種数が最も多く, 17 属 38 種 13 変種を産出している. これらの種のうち, Melosira varians, Fragilaria construens var. subsalina, Synedra ulna, Cocconeis placentula var. euglypta, C. placentula var. lineata, Achnanthes Biasolettiana, A. affiris, A. exigua, Rhoicosphenia curvata, Gyrosigma Kützingii, Navicula cryptocephala, N. cryptocephala var. veneta, N. exigua, Cymbella tumida, Gomphorema argustatum, G. constrictum, G. abbreviatum, Nitzschia obtusa var. 
scalpelliformis, Surirella linearis の 12 属 17 種は，日本全土に広く分布する普遍種で ある。

また Fukushima (1957), Skvortzow (1936) によると, Triceratium Javanicum (= Hydrosera triquetra) 法, 宮城県円田村, Fragilaria virescens var. oblongella, Synedra minuscula は九州屋久島, Synedra amphicephala, Navicula ventralis var. Okamurae 注九州池田湖, Frustulia vulgaris var. asiatica は琵琶湖, Navicula verecunda は九 州大分県山浦村, Gomphonema subclavatum 恃神奈川県芦ノ湖, G. olivaceum var. minutissima 汪, 長野県木崎湖, Nitzschia filiformis var. armata は長野県青木湖に産する.

Fragilaria construens var. subsalina, Pimularia viridis var. sudetica, Nitzschia tryblionella var. levidensis, N. paleaceae は本州中部以南の諸水域で産出する.

また，日本では報告されていない種として, Synedra famelica, Navicula Kuripanensis がある. S. famelica は, スイスの Thun 湖, Zürich で産出し (1930), N. Kuripanensis は, Javaの諸温泉, Sumatra の河川汃らも報告されている(1938).

次に, この地点での珪藻の flora をみる (Table 1), Synedra, Gomphonema, Nitzschia の各属中の種の現存量はきわめて多く, 日本での, 有機污濁を受ける河川での珠藻の flora と似ている，として，渡辺 (1961，1962) か設定した，有機励濁に耐えうる種 (tolerant species）は 19 種出現して，この地点における出現種の半ばを占めている．また，清洌な 水域に出現する種 (intolerant species)の現存量は，前者に比べできわめて少ない。ちな 夕に，珪藻の種類数に基づく，水質の有機污濁に対する生物指数 (1962) 学計算すると， +118 となるが，この值は，京都鴨川の平地部低活濁域での值とほぼ等しい。乙かし，こ の地点では, 前述のように, 人為的な污濁源の存在はほとえど考えられず, 多量の落葉の 分解生成物の溶出による自然污濁が，その誘因になつているのではないか子も思われるが， 流量に対して，過度の落葉堆積が進行した場合の，自然泒濁の問題としても，興味深いも のがある。

Station 2 この地点では, Table 1 に示したように, 13 属 28 種 9 変種 1 品種を産し, Tabellaria flocculosa, Achnanthes affinis, Cymbella ventricosa の現存量が特に大きい が，これらはいずれも河川に普通に出現する世界普遍種である. 次に, 日本では, 比較的 発見回数の少ない種を挙げ，旮机らの分布 $(1957,1936)$ をると，Fragilaria capucina var. lanceolata, Synedra minuscula は九州屋久島, Eunotia indica は三重県有井村, Pinnularia maior var. transversa 注長野県和村, Gomphonema helveticum は長野県 仁田池, Surirella robusta var. armata は, 長野県青木湖に出現し Pinnularia viridis var. sudetica, Nitzschia fonticola は, 本州中部以南の水域から数多く報告されてい る.

Navicula mivima var. atomoides, Pinnularia divergens var. sublinearis は日本で 
は報告された例がないが, 前者は, 中部ヨーロッパの多くの陸水から (1930), 後者は, ヨ ーロッパ諸河川の浅瀬に産出する種である(1902). 上記以外の種は，日本において広い地 域に普通に出現する普遍種である.

次に, Station 2 に出現した種の中で, intolerant species と考えられるものは 15 種, tolerant species と考えられるものは 13 種あり,らち, 11 種は, 広適応性種 (indifferent species), 2 種は，污濁性種 (exclusively pollutional species) と考元られる。いま, St. 1 の場合と同様に, 污濁指数を求めると, +132 となり, この值は, 日本での一般河川の, 污濁を受けない渓流での值とほぼ一致する.

Station 3 この地点に出現した珪藻の種類数は, 他の 2 地点に比べて少なく, 7 属 12 種 6 変種 2 品種を産しているにすぎず, またそれらの現存量も僅少である.これらの種 のうち，日本全土にわたつて広く分布する普遍種と考方秃るものは，Tabellaria flocculosa, Fragilaria virescens, Frustulia rhomboides var. saxonica, Gomphonema angustatum の 4 種のみで，本州中部以南に比較的広く分布する Fragilaria construens var. subsalina, Eunotia pectinalis var. minor, E. pectinalis var. minor fo. impressa を加えても，広い分布をもつ種は 6 種にしかすぎない，他の種は，日本では比較的限られ た場所にしか発見されていない種ばかりであるが，それらの総てについて，産地它略記す ると, Eunotia polydentula 注長野県青木湖, E. pectinalis var. minor fo. intermedia は三重県有井村， E. lunaris var. subarcuata は，埼玉県平方町荒川川跡沼，九州屋久 島, Navicula falaisiensis var. lanceola は長野県木渏湖, 九州池田湖, Pirnularia maior var. transversa は長野県和村で産出している.

Eunotia arcus var. bidens, Nitzschia pseudoamphioxys, N. reversa は, 日本では 報告された例がない種であるが，E.arcus var. bidens は中部ヨーロッパから (1930)， N. pseudoamphioxys は，火山地帯の湖沼の浮游性珪藻として報告されており (1942), N. reversa は, 北米フィラデルフィア近郊の半媙水の水域 (Delaware 河, Duck Creek) で産出している(1916).

この水域の珪藻の flora は, 現存量からすれば, Eunotia 属に包含される数種, および, Frustulia rhomboides var. saxonica によつて代表されると考えられる (Table 1). こ のような珪藻の flora は, 日本の高層湿原での flora と酷似する.

いま, この地点での, 渡辺の活濁指数を求めてみると, tolerant species は皆無で, 出 現する種の総てが, intolerant species であるから，指数は+200になり，理論的な最高 值と一致して，最も清洌な水域であることを示している.

考察と摘要

1. 河川に出現する，珪藻以外の藻類は，普通，ぞの河川でもその種類数が少ないが， Kauai 島の河川の場合も，同様に僅少種の出現を認めたにすぎない，それらの大部分は， 
世界各地に広く分布する普遍種であり，この島に特有の種と考えられるものは，Micras terias truncata の変異型と, Netrium sp. の2 者のみであつた.

また，それら藻類の flora は，日本の河川でのそれとよく似ているが，日本の温泉に産出 する藍藻類が，僅かではあるが，河川中に産出しているのは，生態学的に興味深い事実で ある.

2. Kauai 島の河川に出現した珪藻の種類数は, 19 属 61 種 24 変種 3 品種に達している が (Table 1, Plate 1〜3)，これらのうち，約 1/3の 14 属 21 種 2 変種は世界普遍種であ り，4属 5 種 1 品種は, 日本の本州中部以南に産出する暖性種と考えられる. 残りの 12 属 38 種 15 変種 2 品種のうち, 7 種は，日本では未だ報告された例のない種であり，8 種は九 州からだけ発見されている種である，他の 23 種は，日本では，一部の限られた地域ふら の僅かな報告があるにすぎない種であるが，それらの産地は，大体日本の本州中部以南で ある.

これらの普遍種および日本での限られた水域にのみ発見された種のほとえど総ては, Sumatra, Java, Bali 島の諸水域にも出現するが(1938, 1939), standing crop をも含め ての flora としては, 熱帯の上記諸島の水域の flora よりも，むしろ，日本の河川におけ る flora とよく似ている.

いま，各地点において，特に量産した種について，それらの日本における分布をみると， Station 1 では, Syredra amphicephala, Gomphonema subclavatum, Nitzschia paleaceae, N. filiformis は, 九州, 大阪近辺において発見される種であり, Achnanthes Biasolettiana は，日本の諸河州での普遍種である。また，Station 2,3 では，量産するものの大部分が 普遍種である。

3. 渡辺 $(1961,1962)$ の, 珪藻の種類数に基づく污濁指数の值は, St. $1:+118$, St. 2 : +132, St. 3:+200で, St. 1 のみが低励濁水域であることを示し, St. 2 の值は, 日本 の污濁を受けない一般渓流での值と一致し, St. 3 では, 理論的な最高值と一致して, 最も 清洌な水域であることを示している. St. 3 の珪藻の flora が，高首湿原のとれと酷似する ことからも，湧水の水源が，この Stationの近くにあるのではないかと考えられる. St. 1 での污濁は, 人為的な污濁源の存在は考えられず, 多量の落葉の分解生成物の溶出による, 自然污濁が影響しているものと思われる

$$
\text { 文献 }
$$

Boyer, C. S. : The diatomaceae of Philadelphia and Vicinity, 1-143, J. B. Lippincott Company, Philadelphia, 1916.

Desikachary, T. V. : Cyanophyta, 1-686, Indian Council of Agricultural Resarch, New Delhi, 1959. 
Funushima, H. : A list of Japanese freshwater algae, including the marine species of blue algae and fossil diatoms 4. Journal of Yokohama Municipal Univ., Ser. c-18, No. 71, 1-24, 1957.

Fukushima, H. : Ibid., Ser. c-20, No. 82, 1-52. 1957.

Huber-Pestalozid, G. H. : Die Binnengewässer, Bd, 16, Teil 2, Das Phytoplankton des Susswässers. 367-549, Stuttgart, E. Schweizerbart'sche Verlagsbuchhandlung. 1942.

Hustedt, F. : Die Süsswasser-flora Mitteleuropas. Heft 10, Bacillariophyta (Diatomeae). Zweite Auflage. 1-466, Gustav Fischer, Jena, 1930.

Hustedt, F. : Systematische und Ökologische Untersuchungen über die DiatomeenFlora von Java, Bali und Sumatra Expedition. Fortsetzung. Allgemeiner Teil. 1. Übersicht über das Untersuchungsmaterial und Charakteristik der Diatomeenflora der einzelnen Gebiete. Arch. f. Hydrobiol., Suppl. 15 (Tropische Binnengewässer, 7), 638-790, 1938.

Hustedt, F. : Ibid., Allgemeiner Teil (Schluss.) 3. Die ökologischen Faktoren und ihr Einfluss auf die Diatomeenflora. Suppl. 16 (Tropische Binnengewässer, 8), 274-394, 1939.

Schmidt, A. : Atlas der Diatomaceen-Kunde. Fortgesetzt. v. M. Schmidt, F. Fricke, O. Müller, H. Heiden und F. Hustedt. Aschersleben und Leipzig. 1885-1937.

Skvortzow, B. W. : Diatoms from Biwa Lake, Honshu Island, Nippon. The Philippine Journal of Science Published by the Bureau of Science, Department of Agriculture and Commerce, Manila, P. I., 61, 2, 253-296, 1936.

Skvortzow, B. W. : Diatoms from Ikeda Lake, Satsuma Province, Kiusiu Island, Nippon. Ibid., 62, 2, 191-218, 1937.

渡辺 仿治：鴨川水系における藍藻の種類数に基づく水質污濁の生物指標. 淡水生物， 7 , 11-17, 1961.

渡辺 仁治: 日本生態学会誌, 印刷中.

Watanabe, T.: On the biotic index of water pollution based upon the species number of Bacillariophyceae in the Tokoro River in Hokkaido. Jap. J. Ecol., 12, 6, 216-222 (inJapanese), 1962. 


\section{S UM M A R Y}

The algae attached to the stones were studied on the basis of three samples which were collected by Prof. M. Tsuda in the streams in Kauai, the northernmost island of the Hawaiian Islands, in August, 1961.

1. Many species of diatoms, blue-green algae, green algae and Conjugales were found. They are mostly of cosmopolitan species.

2. The diatoms consist of 19 genera, 61 species, 24 varieties and 3 forms (cf. Table 1, Plates 1-3), of which 21 species are cosmopolitan, while the other 40 species are distributed mostly in the warmer regions.

The diatom flora in the streams in Kauai resembles that in the streams of Japan rather than that in the streams in the tropical islands, Sumatra, Java and Bali. (of. Hustedt 1938, 1939).

3. Watanabe's biotic indices of water pollution based upon the species number of Bacillariophyceae were calculated upon the samples from the three stations under consideration; the values are as follows:
st. $1 \cdots \cdots+118$
st. $2 \cdots \cdots+132$
st. $3 \cdots \cdots+200$

From the above values, the water of the station 1 seems to be slightly polluted ; it may be polluted naturally, not artificially, by fallen leaves, \&c. in the woods. The value of the biotic index of the station 2 is nealy equal to the values obtained in the mountain streams of Japan. The station 3 is considerably high, it showing the highest value which can be obtained by this method of biotic index. The flora of diatoms at this station resembles very much that of high moors in Japan.

（著者：渡辺仁治，奈良女子大学付属高等学校; Toshiharu WATANABE, The Senior High School attached to the Nara Women's University, Nara) 


\section{PLATE I}

1. Melosira varians C. A. Ag.

2,2'. Triceratium Javanicum Cueve

3. Tabellaria flocculosa (Rотн) Küтz.

4. Fragilaria capucina var. lanceolata GRUN.

5. F. construens var. subsalina Hust.

6. F. virescens RALFs

7. F. virescens var. oblongella GRUN.

8. Synedra ulna (Nitzsch) EHr.

9. S. amphicephala Küтz.

$10,10^{\prime}$. S. minuscula Grun.

11. S. famelica Küтz.

12. S. rumpens Küтz.

13. Eunotia praerupta EHR.

14. E. indica Grun.

15. E. arcus var. bidens GRUN.

16. E. polidentula BRUN.

17. E. pectiwalis var. minor (Küтz.) RABH.

18. E. pectinalis var. minor f. impressa (EHR.) Hust.

19. E. pectinalis var. minor f. intermedia KRAssKe

$20,20^{\prime}$. E. pectinalis var. undulata (RALFS) RBH.

21. E. lunaris var. subarcuata (NAEG.) GRUN.

22. Cocconeis placentula var. euglypta (EHR.) $\mathrm{C}_{\mathrm{LEVE}}$

23. C. placentulata var. lineata (EHR.) $\mathrm{C}_{\mathrm{LEVE}}$

$20 \cdots \cdots$ a scale, $2,2^{\prime} \cdots \cdots \mathrm{b}$ scale, other figs. $\cdots \cdots$ c scale

(All figs. original) 
Watanabe : PLATE I

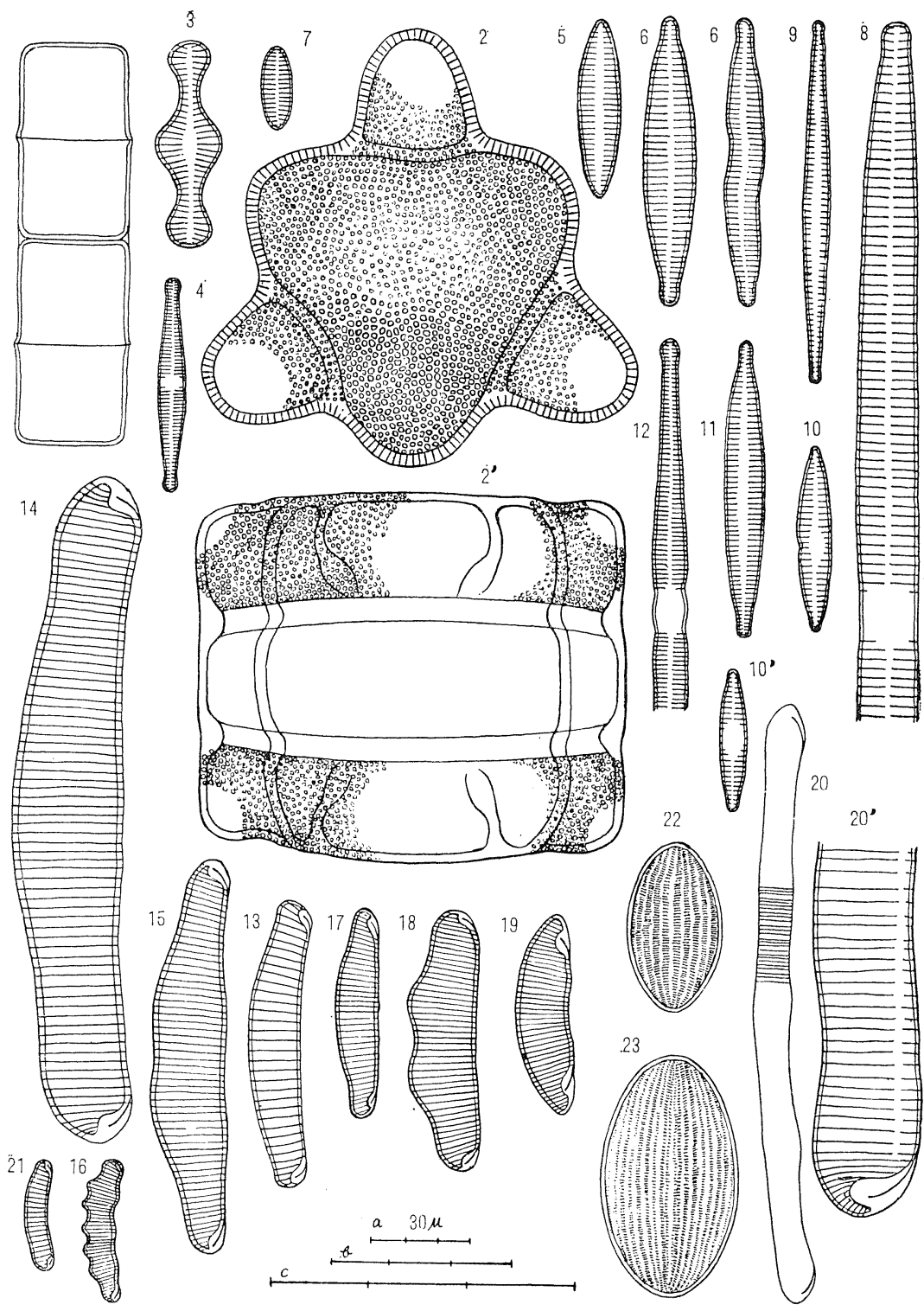




\section{PLATE II}

1. Achnanthes Biasolettiana Kütz.

2. A. affinis GRUN.

3. A. exigua Grun.

4, 4'. Rhoicosphenia curvata (Kütr.) Grun.

5, 5'. Frustulia rhomboides var. saxonica (RABH.) DE TON1

6. F. vulgaris var. asiatica Skv.

7. Gyrosigma Kützingii (GRUN.) CLEVE

8. Navicula minima var. atomoides (GRUN.) Cheve

9. N. mutica Kütz.?

10. N. ventralis var. Okamurae Skv.

11. N. cryptocephala КÜтz.

12. N. cryptocephala var. veneta (Kürz. ) GRUN.

13. N. verecunda Hust.

14. N. falaisiensis var. lanceola Grun.

15. N. exigua (Gregory) O. MüLler

16. N. Kuripanensis Hust.

17. Pinnularia divergens var. sublinearis Cueve

18. P. gibba f. subundulata MAYER

19. P. maior var. transversa A. S.

20. F. viridis var. sudetica (HiLse) Hust.

$19 \cdots \cdots \cdot$ b scale, other figs. $\cdots \cdots \cdot$ c scale

(All figs. original) 


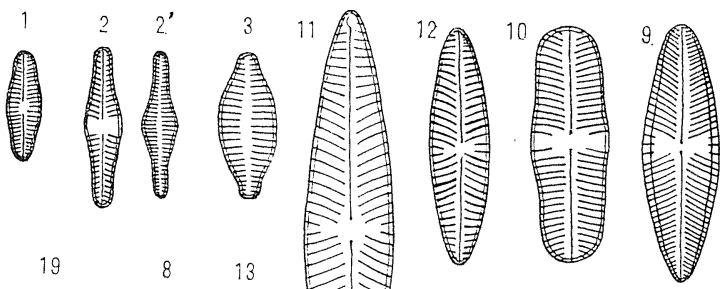

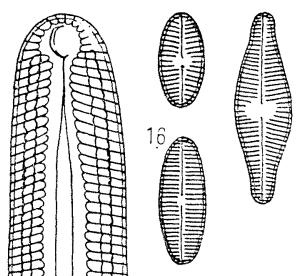

望
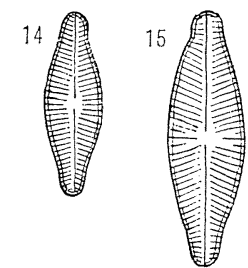

WaTANABE : PLATE II
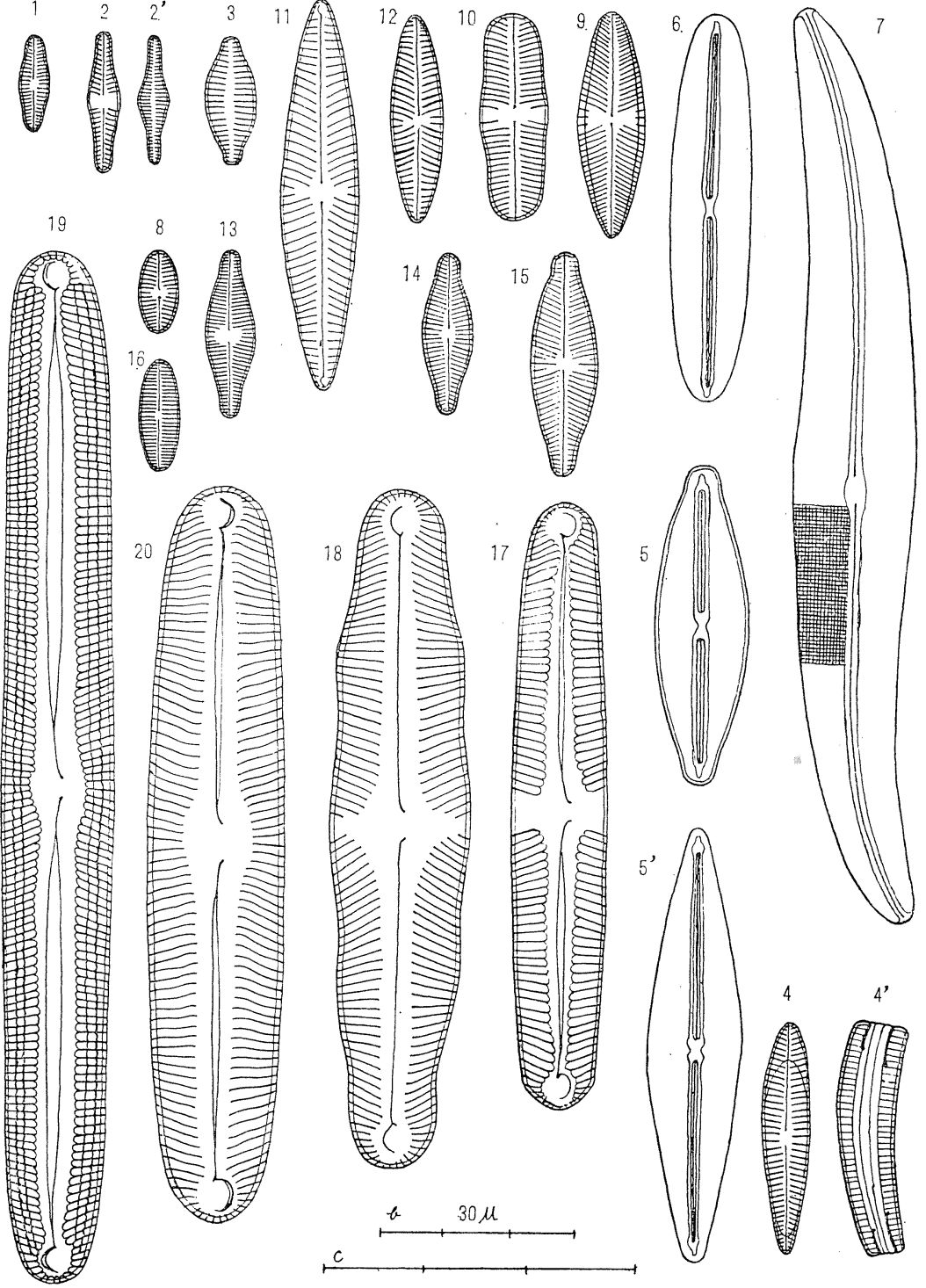


\section{PLATE III}

1. Cymbella turgida (GRegory) $\mathrm{C}_{\mathrm{LEVE}}$

2. C. ventricosa Kütz.

3. C. gracilis (RABH) $\mathrm{C}_{\mathrm{LEVE}}$

4. C. tumida (BRÉBISSON) VAN HEURCK

5. Gomphonema parvulum (Küтz.) GRUNow

6. G. angustatum (KÜтz.) RABH.

7. G. helveticum BRUN.

8. G. longiceps var. subclavata Grun.

9. G. subclavatum GRUN.

10. G. constrictum EHR.

11. G. olivaceum var. minutissima Hust.

12. G. abbreviatum (AGARDH?) KÜTz.

13. Nitzschia tryblionella var. levidensis (W. Smith) GRUn.

14. N. tryblionella var. debilis (ARNotT) A. MAYER

15. N. pseudoamphioxys Hust.

16. N. fonticola Grun.

17. N. paleacea Grun.

18. N. obtusa var. scalpelliformis GRUN.

19. N. filiformis (W. Sмith) Hust.

20. $N$. reversa W. Sмiтн

21. Surirella linearis W. Sмгтн

22. S. angustata Kürz.

23. S. robusta var. armata Hust.

$23 \cdots \cdots \cdot$ b cale, other figs. $\cdots \cdots \cdot c$ scale

(All figs.original) 
Watanabe : PLATE III

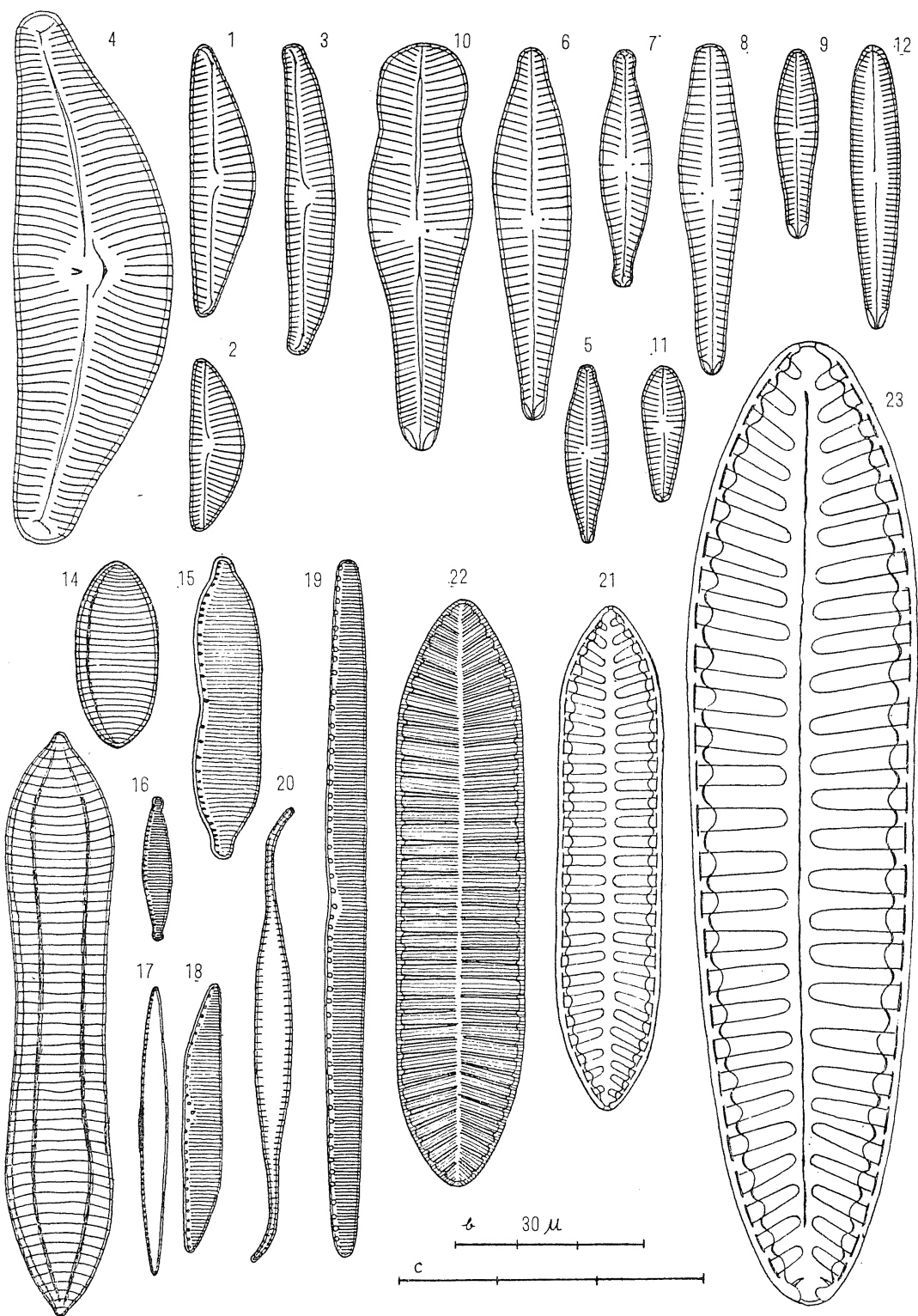

